\title{
Detection of Ralstonia solanacearum in Irrigation Ponds and Aquatic Weeds Associated with the Ponds in North Florida
}

\author{
Jason C. Hong, Plant Pathology Department, University of Florida, IFAS, Gainesville 32611; M. Timur Momol, \\ Plant Pathology Department, North Florida Research and Education Center, University of Florida, Quincy 32351; \\ Jeffrey B. Jones, Plant Pathology Department, University of Florida, IFAS, Gainesville; Pingsheng Ji, North Flor- \\ ida Research and Education Center, University of Florida, IFAS, Quincy 32351; Stephen M. Olson, Horticultural \\ Sciences Department, North Florida Research and Education Center, University of Florida, Quincy; Caitilyn Allen \\ and Amilcar Perez, Department of Plant Pathology, University of Wisconsin-Madison, 53706; Prakash \\ Pradhanang, North Florida Research and Education Center, University of Florida, IFAS, Quincy; and Kiymet \\ Guven, Anadolu University, Department of Biology, Yunus Emre Campus, 26470, Eskisehir, Turkey
}

\begin{abstract}
Hong, J. C., Momol, M. T., Jones, J. B., Ji, P., Olson, S. M., Allen, C., Perez, A., Pradhanang, P., and Guven, K. 2008. Detection of Ralstonia solanacearum in irrigation ponds and aquatic weeds associated with the ponds in North Florida. Plant Dis. 92:1674-1682.

The discovery of exotic Ralstonia solanacearum biovar 1 strains on geranium in north Florida led to a concern that this strain may have become established. Therefore, we monitored irrigation ponds and potential alternative aquatic weeds from 2002 to 2005 for the presence of this strain. We report that this strain, possibly originating from the Caribbean, has become established in several ponds in Gadsden County, FL. Cladistic taxonomy was used to subclassify the bacterium at the species level into four groups or phylotypes based on multiplex polymerase chain reaction of the internal transcribed spacer (ITS) region. The bacterium was further divided into sequevars by sequencing the endoglucanase gene $(e g l)$. The strains were determined to belong to phylotype II/sequevar 4 NPB (nonpathogenic on banana) that was recently reported in Martinique. Partial sequencing of the $e g l$ followed by phylogenetic analysis placed the new Caribbean strains in a different clade than the typical Florida endemic strains. Pulsed-field gel electrophoresis (PFGE) revealed different haplotypes upon comparison of the collected pond strains and the Floridian strains. Based on PFGE polymorphism, egl sequencing, and phylogenetic analysis, the Caribbean strains were shown to be identical to the strain isolated from infected geranium plants. Experiments were undertaken to monitor $R$. solanacearum in irrigation ponds and associated weeds. $R$. solanacearum was detected in surface-disinfested common aquatic weeds growing in the irrigation ponds, including Hydrocotyle ranunculoides (dollar weed) and Polygonum pennsylvanicum (Pennsylvania smart weed). Both weeds were latently infected and showed no signs of wilt when collected. Two different Hydrocotyle spp. were artificially inoculated with $R$. solanacearum under greenhouse conditions and both developed symptoms 14 days post inoculation (dpi) and the bacterium was recovered from the tissues 42 dpi. There was a positive correlation between ambient temperature and $R$. solanacearum populations in irrigation water, as previously shown by other researchers.
\end{abstract}

Additional keywords: alternative hosts, bacterial wilt

Bacterial wilt, caused by Ralstonia solanacearum (28), is one of the most destructive bacterial diseases in the tropical, subtropical, and temperate regions of the world (5). Diseases caused by the bacterium can cause serious yield losses on many crops such as tomato, potato, pepper, eggplant, tobacco, banana, and geranium (Pelargonium spp.; 12). R. solanacearum exhibits both phenotypic and genotypic diversity; thus, classification of this bacte-

Corresponding author: J. B. Jones

E-mail: jbjones@ufl.edu

Accepted for publication 29 August 2008.

doi:10.1094/PDIS-92-12-1674

(C) 2008 The American Phytopathological Society
Urtica dioica (stinging nettle) (2,25). These weeds did not display wilt symptoms and, thus, were not previously recognized as hosts (9). Irrigation water infested with $R$. solanacearum was reported to cause several outbreaks of bacterial wilt on a number of crops (7). Olsson discovered a relationship between farms with infected potato tubers and $S$. dulcamara, a common weed in Sweden (19). During the winter months when air and water temperatures were colder, $R$. solanacearum was not detected in irrigation water, but it was detected in the xylem of adventitious roots of the aquatic weeds (20). Potato brown rot was associated with English farms that irrigated with effluent from the potatoprocessing industry and municipal water purification plants that handled diseased potatoes. Potato fields were irrigated with water from rivers in which latently infected $S$. dulcamara plants were present on the banks and where recycled water from the potato-processing industry and water purification plants emptied (10).

River water temperature was statistically shown to be correlated with the increase of $R$. solanacearum populations of a biovar 2 strain in Spain (3). After a confirmed outbreak of potato brown rot near the Tormes River in Spain, water samples were collected along the river banks at various distances from the infested field over a 3 year period. Populations of $R$. solanacearum biovar 2 were undetectable when the surface water temperature was lower than $14^{\circ} \mathrm{C}$ and were detectable when the temperature was above $14^{\circ} \mathrm{C}$. Once, when the surface water temperature was $8^{\circ} \mathrm{C}$, they were able to recover the bacterium by spread plating on solid medium.

This study was initiated to improve our understanding of the survival of $R$. solanacearum in irrigation water and weed hosts (including aquatic weeds) in Florida. In August 2001, $R$. solanacearum (race 1, biovar 1) was detected on infected geranium plants at an ornamental nursery $(14,16,22)$. Because previous studies had demonstrated the importance of irrigation water and weeds in the epidemiology of $R$. solanacearum race 3 biovar $2(3,7,15)$, 
irrigation ponds on tomato farms and ornamental nurseries were sampled from November 2001 through May 2005 in close proximity to the original outbreak on geranium. In addition to collecting water samples, aquatic and semiaquatic weeds in close proximity to the ponds were tested for the presence of the bacterium in or on plant roots and stems. To determine the genetic relatedness of the native Floridian strain to the strains collected from geranium, strains from the weeds and pond water were compared with a representative Floridian strain using pulsed-field gel electrophoresis (PFGE) and by sequencing part of the endoglucanase gene $(e g l)$ for phylogenetic analysis.

\section{MATERIALS AND METHODS}

Bacterial culture and inoculum preparation. All $R$. solanacearum strains used in this study are listed in Table 1.
Strains RS 5 (race 1, biovar 1) (23) and UF 107 originating from Quincy, FL isolated from a wilted tomato plant and from pond 1 (see below) in July 2004, respectively, were included for comparative purposes. RS 5 represented the native Floridian strains and UF 107 represented the exotic strains collected in this study. The bacteria were grown at $28^{\circ} \mathrm{C}$ on either modified semiselective medium (SMSA; 8 ) or modified casamino acid peptone glucose, (CPG) agar (10 $\mathrm{g}$ of peptone, $1 \mathrm{~g}$ of casamino acid, $2.5 \mathrm{ml}$ of glycerol, $15 \mathrm{~g}$ of agar, and 1 liter of deionized water) replacing glucose with glycerol for $60 \mathrm{~h}$, or in CPG broth on a shaker (100 rpm) for $60 \mathrm{~h}$. Bacterial cells were suspended in sterile tap water and the inoculum concentration was estimated by using a spectrophotometer (Sigma-Aldrich Co., Milwaukee, WI) to measure absorbance at $600 \mathrm{~nm}$. The viable bacterial population was determined following 10 -fold dilution plating on modified SMSA. After the strains were confirmed to be pathogenic by inoculating on Bonny Best tomato as described below, they were stored in $30 \%$ glycerol solution at $-80^{\circ} \mathrm{C}$. Biovar was determined based on the utilization of single sugar alcohols and sugars in media prepared as described by Hayward (12). The putative race was determined by phylogenetic analysis and comparison of previously published strains.

Isolation of $\boldsymbol{R}$. solanacearum from irrigation and retention pond water. Following the initial detection of $R$. solanacearum from an infected geranium plant, water samples were collected from five different irrigation and retention ponds to determine their potential as inoculum sources. The ponds, which are described in the next paragraph, were used for tomato and ornamental plant production in Gadsden County, FL. In order to determine the

Table 1. Ralstonia solanacearum strains used in study ${ }^{\mathrm{x}}$

\begin{tabular}{|c|c|c|c|c|c|c|c|c|}
\hline Strain & Race & Biovar & Phylotype & Sequevar $^{y}$ & Host origin & Origin & $\begin{array}{c}\text { Year } \\
\text { isolated }\end{array}$ & $\begin{array}{c}\text { GenBank } \\
\text { acc. no. }^{\mathrm{z}}\end{array}$ \\
\hline RS 5 & 1 & 1 & II & 7 & Tomato & Quincy, FL & 2000 & Ji et al. (16) \\
\hline RS 37 & 1 & 1 & II & $4 \mathrm{NPB}$ & Geranium & Quincy, FL & 2001 & EU836692 \\
\hline RS 38 & 1 & 1 & II & ND & Geranium & Quincy, FL & 2001 & ND \\
\hline RS 48 & 1 & 1 & II & ND & Tomato & Quincy, FL & 2002 & ND \\
\hline RS 50 & 1 & 1 & II & ND & Tomato & Quincy, FL & 2002 & ND \\
\hline RS 52 & 1 & 1 & II & ND & Pond water & Quincy, FL & 2002 & ND \\
\hline RS 54 & 1 & 1 & II & ND & Creek water & Quincy, FL & 2002 & ND \\
\hline RS 55 & 1 & 1 & II & ND & Bidens mitis & Quincy, FL & 2002 & ND \\
\hline RS 56 & 1 & 1 & II & ND & Polygonum pennsylvanicum & Quincy, FL & 2002 & ND \\
\hline RS 57 & 1 & 1 & II & ND & P. pennsylvanicum & Quincy, FL & 2002 & ND \\
\hline RS 58 & 1 & 1 & II & ND & Hydrocotyle ranunculoides & Quincy, FL & 2002 & ND \\
\hline RS 62 & 1 & 1 & II & ND & Pond water & Quincy, FL & 2002 & ND \\
\hline RS 64 & 1 & 1 & II & ND & Pond water & Quincy, FL & 2002 & ND \\
\hline RS 65 & 1 & 1 & II & ND & Pond water & Quincy, FL & 2002 & ND \\
\hline RS 66 & 1 & 1 & II & ND & Bidens mitis & Quincy, FL & 2002 & ND \\
\hline RS 67 & 1 & 1 & II & ND & Pond water & Quincy, FL & 2002 & ND \\
\hline RS 70 & 1 & 1 & II & ND & P. pennsylvanicum & Quincy, FL & 2002 & ND \\
\hline RS 71 & 1 & 1 & II & ND & Pond water & Quincy, FL & 2002 & ND \\
\hline RS 72 & 1 & 1 & II & ND & Pond water & Quincy, FL & 2002 & ND \\
\hline RS 118 & 1 & 1 & II & $4 \mathrm{NPB}$ & Hydrangea & Quincy, FL & 2004 & NS \\
\hline RS 119 & 1 & 1 & II & $4 N P B$ & Hydrangea & Quincy, FL & 2004 & NS \\
\hline RS 120 & 1 & 1 & II & 4NPB & Hydrangea & Quincy, FL & 2004 & NS \\
\hline RS 125 & 1 & 1 & II & $4 \mathrm{NPB}$ & Geranium & Quincy, FL & 2004 & NS \\
\hline RS 128 & 1 & 1 & II & 4NPB & Geranium & Quincy, FL & 2004 & NS \\
\hline RS 130 & 1 & 1 & II & $4 \mathrm{NPB}$ & Pond water & Quincy, FL & 2004 & NS \\
\hline UF 105 & 1 & 1 & II & $4 N P B$ & Pond water & Quincy, FL & 2004 & NS \\
\hline UF 107 & 1 & 1 & II & $4 N P B$ & Pond water & Quincy, FL & 2004 & NS \\
\hline UF 108 & 1 & 1 & II & $4 \mathrm{NPB}$ & P. pennsylvanicum & Quincy, FL & 2004 & NS \\
\hline UF 312 & 1 & 1 & II & $4 \mathrm{NPB}$ & H. ranunculoides & Quincy, FL & 2004 & NS \\
\hline UF 334 & 1 & 1 & II & 4NPB & Geranium & Quincy, FL & 2005 & NS \\
\hline CFBP6801 & ND & ND & II & $4 N P B$ & Heliconia caribea & Gros Morne, Martinique & 2001 & EF371836 \\
\hline K60 & 1 & 1 & II & 7 & Tomato & Raleigh, NC & 1954 & EF192970 \\
\hline MAFF301558 & 3 & $2 \mathrm{~T}$ & IV & 8 & Potato & Japan & ND & DQ657634 \\
\hline NCPPB283 & ND & 1 & III & ND & Solanum panduriforme & Zimbabwe & ND & AF295275 \\
\hline NCPPB332 & ND & 1 & III & ND & Potato & Zimbabwe & ND & DQ657649 \\
\hline NCPPB 1018 & ND & 1 & III & ND & Potato & Angola & ND & AF295271 \\
\hline NCPPB3190 & ND & 3 & I & ND & Tomato & Malaysia & ND & AF295253 \\
\hline UW9 & 1 & 1 & II & 3 & Heliconia sp. & Costa Rica & 1968 & AF295257 \\
\hline UW154 & 1 & 1 & II & ND & Tobacco & Colombia & 1966 & NS \\
\hline UW477 & 3 & $2 \mathrm{~T}$ & II & ND & Potato & Peru & 1979 & AF295260 \\
\hline UW551 & 3 & 2 & II & 1 & Geranium & Kenya & 2003 & DQ657596 \\
\hline RSYR058 & R. syzgii & $\ldots$ & IV & 9 & Clove & Indonesia & 1985 & DQ011543 \\
\hline
\end{tabular}

${ }^{x}$ Phylotype, sequevar, race, biovar, host, origin, and date for the strains other than those characterized in this study are from the literature. ND $=$ not determined.

y Sequevar was determined by previously published sequences $(11,25)$ and based on grouping by phylogenetic analysis.

${ }^{\mathrm{z}}$ GenBank accession numbers for endoglucanase gene sequences were obtained from http://www.ncbi.nlm.nih.gov/; NS = not submitted to GenBank but sequences were identical to RS 37. 
relationship between air temperature and $R$. solanacearum populations in pond water, the average air temperature for each month was recorded at the weather station located at the North Florida Research and Education Center in Gadsden County. All the ponds were within a 15 -mile radius from the research station. Surface water samples from each pond were collected in a 7.6-liter metal bucket and transferred to sterile 50-ml capped tubes (Falcon, Becton, Dickinson and Company, Franklin Lakes, NJ). Whenever possible, water samples were collected in close proximity to aquatic weeds, namely Hydrocotyle ranunculoides and Polygonum pennsylvanicum, because these weeds were suspected to be symptomless hosts. From each of the surface water samples, $1 \mathrm{ml}$ of nondiluted and a 10-fold serial dilution of each sample were spread onto modified SMSA; this was replicated four times for each sample, and the plates were incubated at $28^{\circ} \mathrm{C}$ for 60 h. From November through April, the water samples were concentrated by centrifugation, because the bacterium was undetectable by the previous method. Each water sample $(30 \mathrm{ml})$ was centrifuged at $7,826 \mathrm{~g}$ for $10 \mathrm{~min}$ at $28^{\circ} \mathrm{C}$. All but $100 \mu \mathrm{l}$ of the supernatant was discarded and the pellet was resuspended in the remaining supernatant. Nondiluted and 10 -fold serial dilutions of each sample were spread onto modified SMSA. On this medium, pathogenic colonies of $R$. solanacearum were selected from the spread plates and transferred to modified SMSA; pathogenic colonies initially appeared white, then marbled with purple, and were mucoid, and nonpathogenic colonies were solid purple and dry. All of the selected colonies were confirmed by whole-cell fatty acid methyl ester analysis (FAME; 18) and pathogenicity assay on tomato as described below.

Pond 1, previously identified by $\mathrm{Ji}$ et al. (16), was located at an ornamental nursery and was shown to be a source of inoculum. The pond was a retention pond heavily vegetated with various aquatic weeds, including Tripsacum floridana, Alternanthera philoxeroides (alligator weed), Lemnaceae spp. (duckweed), H. ranunculoides (dollar weed), P. pennsylvanicum, and Persea palustris (swamp bay). Greenhouse irrigation runoff water collected into this pond. Five water samples were collected monthly, as described above, from the banks of this pond from August 2003 until August 2004. Given that pond 1 was shown by Ji et al. (16) to be a source of inoculum, the weeds in that pond were suspected of being potential hosts for the pathogen. Therefore, the remaining ponds were surveyed for weeds similar to those found in pond 1 . Pond 2 was located in the middle of a tomato grower's field and contained the same weeds as pond 1. Water samples were taken monthly from August 2003 to May 2005 from four locations along the banks of the pond. Pond 3 was located on a different tomato grower's field where bacterial wilt was previously reported and was the largest pond surveyed. It was situated in a valley of wooded hills and was fed by local streams. Duckweed was the only similar weed in pond 3 that was also present in ponds 1 and 2. Water samples were collected monthly from four different locations around the pond from August 2003 through May 2005. Pond 4, which was located on the same farm as pond 3 and which was the smallest of all the ponds surveyed, contained no weeds similar to those found in ponds 1 and 2. Pond 4 was a water retention pond that was situated in an unused field and was dry until April 2004, after which time water accumulated and monthly sampling commenced. Pond 5 , which was located on another tomato farm, was added to the sampling scheme in May 2004 because bacterial wilt was detected in tomato plants in the fields irrigated with water from that pond. The pond surface was completely and solely covered with duckweed year round and it was surrounded by hills on all sides. Two water samples were periodically taken from the pond until the end of the study.

As a result of consistent isolation of $R$. solanacearum over the course of the study from ponds 1 and 2, strains from these two ponds were characterized to determine biovar, sequevar, and PFGE with some of the strains to identify haplotypes. These techniques, when used together, could potentially help in determining if the strains being collected were endemic or nonnative.

The monthly bacterial populations of all ponds were calculated by performing a serial dilution of each sample and plating on modified SMSA for $72 \mathrm{~h}$. The $R$. solanacearum colonies were counted and the average for all the samples corresponding to each pond were used to estimate the population size for each pond for each month. The monthly population sizes for each pond were $\log$ transformed $\left(z=\log _{10}\right.$ $[y+1])$, and then the correlations of the monthly population size compared with the monthly air temperature were statistically analyzed using Spearman's correlation coefficient by the SAS System for Windows program (release 8.02; SAS, Cary, NC).

Each strain collected and confirmed as being $R$. solanacearum by FAME was tested for pathogenicity by inoculating 3to 4-week-old tomato plants (cv. Bonny Best) in 10-cm pots. Initially, root inoculations were performed by stabbing around the base of the plants to damage the roots. Following wounding, $10 \mathrm{ml}$ of a bacterial suspension adjusted to $10^{8} \mathrm{CFU} / \mathrm{ml}$ was poured around the crown of tomato plants. The inoculated plants were transferred to a growth room with a 12-h light-and-dark cycle and air temperature maintained at $28^{\circ} \mathrm{C}$. This method was replaced by a toothpick method in which symptoms were produced more quickly and consistently. The toothpick method involved stabbing the lower stem of the tomato plants near the crown with a toothpick laden with bacteria from inoculum grown on modified $\mathrm{CPG}$ agar for $24 \mathrm{~h}$ at $28^{\circ} \mathrm{C}$. Each strain was inoculated into three plants. Tomato plants that developed wilt symptoms were tested for $R$. solanacearum by reisolating on modified SMSA and typical colonies were analyzed by FAME. Strains that caused wilt symptoms and were confirmed as $R$. solanacearum were stored in sterile $30 \%$ glycerol solution at $-80^{\circ} \mathrm{C}$.

Monitoring $R$. solanacearum in aquatic weeds associated with irrigation ponds. Plants collected at the banks of the ponds were monitored to determine whether they harbored $R$. solanacearum. The survey was conducted at ponds 1 and 2 , where the bacterium was found consistently. Weeds common to pond 1 and pond 2 were collected and taken to the Center for Aquatic and Invasive Plants, University of Florida in Gainesville for identification. Identified plants were selected and samples were analyzed for the presence of $R$. solanacearum as follows. Each plant was washed under tap water to remove loose soil particles and was then divided into a root section consisting of all root parts below the crown and a stem section consisting of the stem between the crown and cotyledon. The stolons were added to the stem section where applicable. The root and stem sections were then divided into two subgroups and were surface sterilized or untreated. The sections that were surface sterilized were soaked in $70 \%$ ethyl alcohol for $5 \mathrm{~min}$ and then washed with sterile tap water. This was repeated three times. The sections were placed in separate, clear 2-mil plastic bags (Gainesville Paper Co., Gainesville, FL) and crushed using a pestle. Sterile water $(1 \mathrm{ml})$ was added to the macerated samples and, after $20 \mathrm{~min}, 10$-fold serial dilutions were prepared and transferred to modified SMSA plates. Plates were incubated for $60 \mathrm{~h}$ at $28^{\circ} \mathrm{C}$. Putative $R$. solanacearum colonies were selected and analyzed by FAME analysis. Confirmed $R$. solanacearum colonies were tested for pathogenicity by the toothpick method as described previously and the pathogen was reisolated from wilted tomato plants and stored in sterile $30 \%$ glycerol solution at $-80^{\circ} \mathrm{C}$.

From November until April, the plant sample extracts were concentrated by centrifugation, because the bacterium was present at very low levels. One milliliter of extract from the crushed plant samples was centrifuged at $10,000 \mathrm{rpm}$ for $10 \mathrm{~min}$ at $28^{\circ} \mathrm{C}$. All of the supernatant was discarded, and the pellet was resuspended in $400 \mu \mathrm{l}$ of sterile water. Nondiluted and 10 -fold serial dilutions of each sample were spread onto modified SMSA incubated at $28^{\circ} \mathrm{C}$ for 60 
h. Suspected $R$. solanacearum colonies were characterized as described previously.

Assay for colonization of $\boldsymbol{H}$. ranunculoides and $H$. bonariensis by $R$. solanacearum. $H$. ranunculoides and $H$. bonariensis were collected from pond 2 . The plants were transplanted in expanded polystyrene flats with the cells filled with Terra-Lite agricultural mix (Scott Sierra
Horticultural Products Co., Marysville, $\mathrm{OH}$ ). Polygonum pennsylvanicum could not be grown in greenhouse conditions and, therefore, was not used in host range experiments. Each cell consisted of three stems that were connected by a rhizomic stem. Five days after transplanting, $10 \mathrm{ml}$ of bacterial suspensions produced from strains RS 5 and UF 107 adjusted to $1 \times$

Table 2. Estimates of Ralstonia solanacearum populations in five irrigation ponds in Gadsden County, FL between August 2003 and May 2005

\begin{tabular}{|c|c|c|c|c|c|}
\hline Months & Pond 1 & Pond 2 & Pond 3 & Pond 4 & Pond 5 \\
\hline August 2003 & 0 & 0 & 0 & NS & NS \\
\hline September 2003 & 0 & 0 & 0 & NS & NS \\
\hline October 2003 & 0 & 0 & 0 & NS & NS \\
\hline November 2003 & 0 & 0 & 0 & NS & NS \\
\hline December 2003 & 0 & 0 & 0 & NS & NS \\
\hline January 2004 & 0 & 0 & 0 & NS & NS \\
\hline February 2004 & 0 & 0 & 0 & NS & NS \\
\hline March 2004 & 0 & 0 & 0 & NS & NS \\
\hline April 2004 & $4.2 \times 10^{2}$ & 0 & 0 & 0 & NS \\
\hline May 2004 & $5.6 \times 10^{3}$ & 0 & 0 & 0 & 0 \\
\hline June 2004 & $3.2 \times 10^{3}$ & $3.5 \times 10^{2}$ & 0 & 0 & 0 \\
\hline July 2004 & $3.9 \times 10^{4}$ & $3.6 \times 10^{3}$ & 0 & 0 & 0 \\
\hline August 2004 & $3.9 \times 10^{3}$ & $6.8 \times 10^{3}$ & 0 & 0 & 0 \\
\hline September 2004 & NS & $9.3 \times 10^{3}$ & 0 & 0 & 0 \\
\hline October 2004 & NS & $5.6 \times 10^{4}$ & $2.4 \times 10^{2}$ & $3.7 \times 10^{2}$ & 0 \\
\hline November 2004 & NS & $2.9 \times 10^{2}$ & 0 & 0 & 0 \\
\hline December 2004 & NS & 0 & 0 & 0 & 0 \\
\hline January 2005 & NS & 0 & 0 & 0 & 0 \\
\hline February 2005 & NS & 0 & 0 & 0 & 0 \\
\hline March 2005 & NS & 0 & 0 & 0 & 0 \\
\hline April 2005 & NS & 0 & 0 & 0 & 0 \\
\hline May 2005 & NS & 0 & 0 & 0 & 0 \\
\hline
\end{tabular}

z NS = not sampled.

Table 3. Incidence and population estimates of Ralstonia solanacearum in water samples from five ponds in Gadsden County, FL by direct isolation on modified semiselective medium agar from August 2003 to May 2005

\begin{tabular}{lccc}
\hline & \multicolumn{2}{c}{$\begin{array}{c}\text { No. of positive samples/ } \\
\text { total no. of samples }\end{array}$} & \\
\cline { 2 - 3 } Pond & $\mathbf{2} \mathbf{1 7}^{\circ} \mathbf{C}$ & $\boldsymbol{R}$. solanacearum concentration (CFU/ml) \\
\hline 1 & $5 / 13$ & $0 / 13$ & $4.2 \times 10^{2}-3.9 \times 10^{4}$ \\
2 & $5 / 22$ & $1 / 22$ & $2.9 \times 10^{2}-5.6 \times 10^{4}$ \\
3 & $1 / 13$ & $0 / 13$ & $2.4 \times 10^{2}$ \\
4 & $1 / 24$ & $0 / 24$ & $3.7 \times 10^{2}$ \\
5 & $0 / 13$ & $0 / 13$ & 0 \\
Total & $12 / 84$ & $1 / 84$ & $\ldots$ \\
\hline
\end{tabular}

$10^{8} \mathrm{CFU} / \mathrm{ml}$ were poured separately into cells. Twelve plants of each species were inoculated and maintained under greenhouse conditions $\left(27\right.$ to $32^{\circ} \mathrm{C}$ ) for 42 days with daily watering. The tomato cv. Solarset was used as a control and was also grown in greenhouse conditions. Each treatment consisted of each plant species and strain combination applied to three plants, and the treatments were replicated four times. The roots and stems of the inoculated plants were tested for $R$. $s o$ lanacearum colonization as previously described.

PFGE analysis of $R$. solanacearum strains. Nineteen representative $R$. solanacearum strains collected from ponds 1,2 , and 3 in 2002 were compared with RS 5, a typical Florida strain, and Rs37, isolated from geranium in 2001, by PFGE as previously described (6). Whole-cell DNA (6) from representative $R$. solanacearum strains was digested with $X b a \mathrm{I}$ or $D r a \mathrm{I}$ and analyzed.

Sequence analysis of $e g l$ for phylogenetic analysis. The primer pair Endo-F (ATGCATGCCGCTGGTCGCCGC) and Endo-R (GCGTTGCCCGGCACGAAC ACC) was used to amplify a 750-bp fragment of the $R$. solanacearum egl. Reactions contained $1 \times P f u$ polymerase buffer, $0.25 \mathrm{mM}$ each dNTP; $6 \%$ dimethyl sulfoxide, $100 \mathrm{pmol}$ of each primer; $100 \mathrm{ng}$ of template DNA, and $2.5 \mathrm{U}$ of $P f u$ Ultra High Fidelity Polymerase (Stratagene, Inc., La Jolla, CA) in a final volume of 50 $\mu \mathrm{l}$. The $e g l$ sequence was amplified using a 3-min hot start at $96^{\circ} \mathrm{C}$, followed by 30 cycles of $30 \mathrm{~s}$ at $95^{\circ} \mathrm{C}, 45 \mathrm{~s}$ at $69^{\circ} \mathrm{C}$, and 2 min at $72^{\circ} \mathrm{C}$, with a final 10 -min extension step at $72^{\circ} \mathrm{C}$. The amplified fragments were ligated into the pCR Blunt II-TOPO vector (Invitrogen, Inc., Carlsbad, CA), according to the manufacturer's instructions. The ligation mixture was electroporated into competent Escherichia coli DH5 $\alpha$ cells, plated onto Luria Bertani (LB) agar plus kanamycin at $25 \mu \mathrm{g} / \mathrm{ml}$, and incubated overnight at $37^{\circ} \mathrm{C}$. White colo-

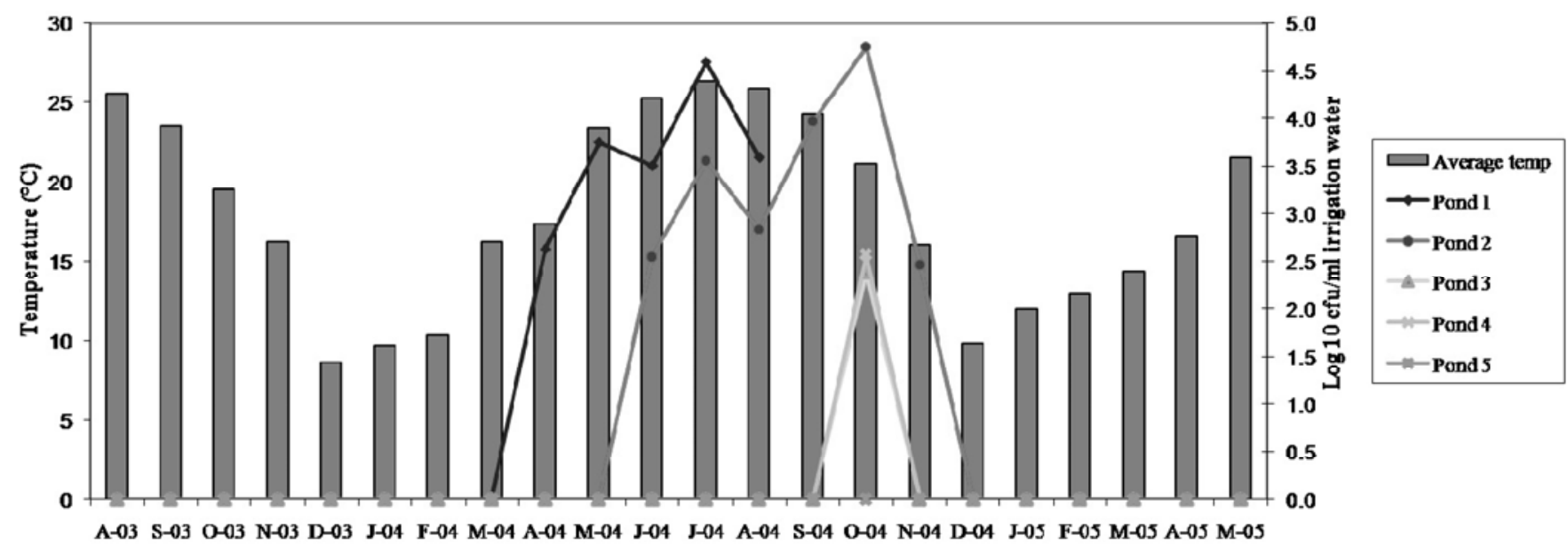

Fig. 1. Ralstonia solanacearum populations by direct isolation on modified semiselective medium during a survey of five ponds. The dates indicate the sampling months from 2003 to 2005 . The populations of the bacterium and the air temperatures at the time the samples were taken are indicated. 
Table 4. Detection of Ralstonia solanacearum in stems and roots of Polygonum pennsylvanicum and Hydrocotyle ranunculoides associated with irrigation ponds 1 and 2 in Gadsden County, FL from July 2004 to May 2005

\begin{tabular}{|c|c|c|c|c|}
\hline \multirow[b]{2}{*}{ Month sampled } & \multirow[b]{2}{*}{ Plants } & \multirow[b]{2}{*}{ R. solanacearum $^{\mathrm{x}}$} & \multicolumn{2}{|c|}{ Bacteria isolated from } \\
\hline & & & Root & Stem \\
\hline \multirow[t]{2}{*}{ July 2004} & P. pennsylvanicum & + & + & + \\
\hline & H. ranunculoides & + & + & + \\
\hline August 2004 & H. ranunculoides & + & + & + \\
\hline \multirow[t]{2}{*}{ September 2004} & P. pennsylvanicum & + & + & + \\
\hline & H. ranunculoides & $++^{\mathrm{y}}$ & + & - \\
\hline \multirow[t]{2}{*}{ October 2004} & P. pennsylvanicum & + & + & + \\
\hline & H. ranunculoides & + & + & + \\
\hline \multirow[t]{2}{*}{ November 2004} & P. pennsylvanicum & $++^{\mathrm{y}, \mathrm{z}}$ & $t^{\mathrm{z}}$ & $-{ }^{\mathrm{z}}$ \\
\hline & H. ranunculoides & $++^{\mathrm{y}, \mathrm{z}}$ & $t^{\mathrm{z}}$ & $-{ }^{\mathrm{z}}$ \\
\hline December 2004 & H. ranunculoides & $-^{\mathrm{z}}$ & $-^{\mathrm{z}}$ & $-^{\mathrm{z}}$ \\
\hline January 2005 & H. ranunculoides & $-\mathrm{z}$ & $-\mathrm{z}$ & $-\mathrm{z}$ \\
\hline February 2005 & H. ranunculoides & $-\mathrm{z}$ & $--^{\mathrm{z}}$ & $-{ }^{\mathrm{z}}$ \\
\hline March 2005 & H. ranunculoides & $--^{\mathrm{z}}$ & $--^{\mathrm{z}}$ & $-{ }^{\mathrm{z}}$ \\
\hline April 2005 & H. ranunculoides & $--^{\mathrm{z}}$ & $-{ }^{\mathrm{z}}$ & $-{ }^{\mathrm{z}}$ \\
\hline \multirow[t]{2}{*}{ May 2005} & H. ranunculoides & $++^{y}$ & + & + \\
\hline & P. pennsylvanicum & $+^{\mathrm{y}}$ & + & - \\
\hline
\end{tabular}

${ }^{x}$ Detection of $R$. solanacearum. Roots and stems from each plant were divided in two groups. One half of the plant material was macerated in $1 \mathrm{ml}$ of sterile water and the other half was surface sterilized, then macerated in $1 \mathrm{ml}$ of sterile water. The macerates were streaked on modified semiselective medium and were incubated at $28^{\circ} \mathrm{C}$. R. solanacearum was detected on sterilized samples unless indicated otherwise.

y $R$. solanacearum found on both sterilized and nonsterilized samples.

${ }^{\mathrm{z}}$ Samples were concentrated by centrifugation.

Table 5. Bacterial wilt incidence on Hydrocotyle ranunculoides and tomato in one experiment and Hydrocotyle bonariensis and tomato in a second experiment after inoculation with Ralstonia solanacearum strains RS 5 and UF 107 under greenhouse conditions

\begin{tabular}{|c|c|c|c|c|}
\hline \multirow[b]{2}{*}{ Host, $R$. solanacearum strain $^{z}$} & \multicolumn{4}{|c|}{ Plants wilted after inoculation $(\%)^{\mathrm{y}}$} \\
\hline & Day 10 & Day 14 & Day 21 & Day 28 \\
\hline \multicolumn{5}{|l|}{ Experiment 1} \\
\hline \multicolumn{5}{|l|}{ Tomato } \\
\hline UTC & $0.0 \mathrm{c}$ & $0.0 \mathrm{~d}$ & $0.0 \mathrm{c}$ & $0.0 \mathrm{c}$ \\
\hline RS 5 & $50.0 \mathrm{a}$ & $100.0 \mathrm{a}$ & $100.0 \mathrm{a}$ & $100.0 \mathrm{a}$ \\
\hline UF 107 & $33.3 \mathrm{~b}$ & $75.0 \mathrm{~b}$ & $91.7 \mathrm{a}$ & $91.7 \mathrm{a}$ \\
\hline \multicolumn{5}{|l|}{ H. ranunculoides } \\
\hline UTC & $0.0 \mathrm{c}$ & $0.0 \mathrm{~d}$ & $0.0 \mathrm{c}$ & $0.0 \mathrm{c}$ \\
\hline RS 5 & $0.0 \mathrm{c}$ & $8.3 \mathrm{~cd}$ & $8.3 \mathrm{c}$ & $8.3 \mathrm{c}$ \\
\hline UF 107 & $0.0 \mathrm{c}$ & $25.0 \mathrm{c}$ & $25.0 \mathrm{~b}$ & $25.0 \mathrm{~b}$ \\
\hline LSD & 11.8 & 17.4 & 15.7 & 15.7 \\
\hline \multicolumn{5}{|l|}{ Experiment 2} \\
\hline \multicolumn{5}{|l|}{ Tomato } \\
\hline UTC & $0.0 \mathrm{~b}$ & $0.0 \mathrm{~b}$ & $0.0 \mathrm{~b}$ & $0.0 \mathrm{~b}$ \\
\hline RS 5 & $66.7 \mathrm{a}$ & $91.7 \mathrm{a}$ & $91.7 \mathrm{a}$ & $100.0 \mathrm{a}$ \\
\hline UF 107 & $58.3 \mathrm{a}$ & $75.0 \mathrm{a}$ & $83.3 \mathrm{a}$ & $83.3 \mathrm{a}$ \\
\hline \multicolumn{5}{|l|}{ H. bonariensis } \\
\hline UTC & $0.0 \mathrm{~b}$ & $0.0 \mathrm{~b}$ & $0.0 \mathrm{~b}$ & $0.0 \mathrm{~b}$ \\
\hline RS 5 & $0.0 \mathrm{~b}$ & $0.0 \mathrm{~b}$ & $0.0 \mathrm{~b}$ & $0.0 \mathrm{~b}$ \\
\hline UF 107 & $0.0 \mathrm{~b}$ & $8.3 \mathrm{~b}$ & $16.7 \mathrm{~b}$ & $16.7 \mathrm{~b}$ \\
\hline LSD & 10.3 & 17.4 & 18.2 & 16.8 \\
\hline
\end{tabular}

y The two experiments consisted of four replications with three plants per treatment in each replication. Similar letters in each column indicates no significant difference according to least significant difference (LSD) test at $P \leq 0.05$.

${ }^{\mathrm{z}} \mathrm{UTC}=$ Untreated control and LSD at $P=0.05$.

Table 6. Percent recovery of Ralstonia solanacearum from surfaced-sterilized and nonsterilized Hydrocotyle ranunculoides tissues following inoculation with two strains under greenhouse conditions ${ }^{\mathrm{z}}$

\begin{tabular}{lccccc}
\hline & \multicolumn{2}{c}{ Nonsterilized } & & \multicolumn{2}{c}{ Sterilized } \\
\cline { 2 - 3 } \cline { 5 - 6 } R. solanacearum strain & Root & Rhizome and petiole & & Root & Rhizome and petiole \\
\hline UTC & $0.0 \mathrm{c}$ & $0.0 \mathrm{~b}$ & & $0.0 \mathrm{~b}$ & $0.0 \mathrm{~b}$ \\
RS 5 & $41.7 \mathrm{~b}$ & $41.7 \mathrm{a}$ & & $33.3 \mathrm{ab}$ & $25.0 \mathrm{ab}$ \\
UF 107 & $75.0 \mathrm{a}$ & $66.7 \mathrm{a}$ & & $58.3 \mathrm{a}$ & $58.3 \mathrm{a}$ \\
LSD $(P=0.05)$ & 31.1 & 35.0 & & 34.2 & 34.2 \\
\hline
\end{tabular}

z Values were derived from 12 plants for each treatment. Sterilization of plant tissues was done by soaking in $70 \%$ alcohol for $5 \mathrm{~min}$ and then rinsing in sterile distilled water three times. Similar letters in each column indicate no significant difference according to least significant difference (LSD) test at $P \leq 0.05$. UTC $=$ untreated control. nies, representing potential transformed cells, were screened by polymerase chain reaction using the Endo-F/Endo-R primer pair and the standard Taq polymerase reaction conditions described above. Plasmids from colonies yielding a 750-bp amplicon were isolated using a standard protocol (1), and the cloned DNA inserts were sequenced in both directions at the University of Wisconsin Biotechnology Center. Sequences were analyzed using the Jellyfish 3.0 software package (LabVelocity, Burlingame, CA). Sequences were stored in the Biology Workbench database (http://workbench.sdsc.edu), combining the sequences reported here with diverse $R$. solanacearum egl sequences previously deposited in the GenBank database (Table 1).

Phylogenetic trees were built by first aligning the nucleotide sequence automatically using ClustalX (CLUSTAL X Multiple Sequence Alignment Program version 1.81, June 2000) and then adjusting the alignment manually using MacClade (version 4.0; Sinauer Associates). PAUP* version 4.0b10 (24) was used for analysis and creating parsimony consensus trees, parsimony bootstrap trees, maximum likelihood (ML) trees, ML bootstrap trees, and Bayesian consensus trees. Parsimony trees were created using the default settings and performing a heuristic search that resulted in one tree. Bootstrap analysis for the parsimony tree was performed with 1,000 bootstrapping replicates. For ML analysis, PAUP* performed a heuristic search under the default ML settings, which resulted in the initial tree and the base likelihood score. The data were than analyzed by assessing models for nucleotide substitution using the ML approach as implemented in the program Modeltest 3.7 (21). A best-fit nucleotide substitution model was selected for our set of aligned sequences, and model selection was conducted on the basis of hierarchal likelihood ratio tests (hLRT). The best-fit model from the likelihood settings was the $(\mathrm{GTR}+\mathrm{G})$ selected by Akaike's information criterion (AIC). ML bootstrap analysis was performed with 1,000 bootstrapping replicates. Bayesian analysis was performed by using Mr. Bayes 3.1 (13). Settings for the analysis were set at 1,000,000 generations, sampled at every 100 generations. The burn-in was set at sample 301 and the consensus trees were created by PAUP*.

\section{RESULTS}

Monitoring $R$. solanacearum in irrigation pond water. $R$. solanacearum was detected consistently throughout the sampling period when the temperature was above $17^{\circ} \mathrm{C}$ in ponds 1 and 2 , once each in ponds 3 and 4, and never in pond 5 (Table $2) . R$. solanacearum was isolated from 13 of 84 samples (16.6\%; Table 3). All isolated colonies from ponds caused wilt symptoms within 4 to 5 days post inoculation (dpi) on inoculated tomato plants, 
whereas RS 5 required 7 to 9 days for symptom development.

$R$. solanacearum population in pond water was indirectly related to the average air temperature in the month in which the samples were collected (Fig. 1; Table $3)$. The air temperatures during the testing period ranged from 16.0 to $26.3^{\circ} \mathrm{C}$. The air temperature was above $23^{\circ} \mathrm{C}$ when the pathogen was detected in eight of the water samples. The lowest air temperature associated with recovery of the bacterium was $16^{\circ} \mathrm{C}$ in November 2004; however, the sample was concentrated. During the winter months, December through March, when the average air temperature was less than $17^{\circ} \mathrm{C}, R$. solanacearum was not recovered. The bacterial populations in pond water ranged from $2.4 \times 10^{2}$ to $5.6 \times 10^{4} \mathrm{CFU} / \mathrm{ml}$. Statistical analysis revealed a significant positive correlation between $R$. solanacearum population levels and air temperature at the time of sampling for ponds 1 and 2. Pond 1 gave a Spearman's rank correlation coefficient $\left(\mathrm{r}_{\mathrm{s}}\right)$ of 0.596 and a $P$ value of 0.0034 , and pond 2 had an $\mathrm{r}_{\mathrm{s}}$ of 0.626 and a $P$ value of 0.0014 .

Monitoring $R$. solanacearum populations in aquatic weeds associated with irrigation ponds. Weeds included T. floridana; water surface weeds A. philoxeroides (alligator weed), Lemnaceae spp. (duckweed), $H$. ranunculoides (dollar weed), and $P$. pennsylvanicum; and the tree Persea palustris (swamp bay). H. ranunculoides and Polygonum pennsylvanicum were the only weeds from which $R$. solanacearum was detected (data not shown). From July to October $2004 R$. solanacearum was isolated from the surface or internal tissue of $H$. ranunculoides and $P$. pennsylvanicum (Table 4). Although the bacterium was isolated from both the stems and roots, $64 \%$ of the positive results were from roots. $R$. solanacearum was isolated from $61 \%$ of the surface-sterilized samples. $R$. solanacearum was not detected on the weeds during the winter months and $P$. pennsylvanicum did not grow in the ponds from December to May, whereas $H$. ranunculoides grew year-round. The pathogen was again recovered in May 2005 after not being detected during the intervening 5 months. In November, the pathogen was recovered once on nonsurface-sterilized root samples of $P$. pennsylvanicum and $H$. ranunculoides (Table 4 ).

Inoculation of $H$. ranunculoides and $H$. bonariensis with $R$. solanacearum. Tomato plants and two Hydrocotyle spp. were inoculated with RS 5 and UF107. Of the Hydrocotyle plants inoculated with RS $5,8 \%$ showed wilt symptoms, whereas $25 \%$ of the plants inoculated with UF107 wilted by day 14 . Each pot with a Hydrocotyle sp. contained three stems and leaves that were connected by a rhizomic stem. However, not all stems and leaves within each pot displayed symptoms. Two weeks after symptoms were observed, the Hydrocotyle plants began to regenerate and no further wilt symptoms developed throughout the remainder of the trial. When sampling inoculated plants to determine the extent of bacterial colonization (Table 5), RS 5 was detected on $41 \%$ of the nonsterilized plant parts, whereas 33 and $25 \%$ of surface-sterilized roots and rhizomes, respectively, were positive for the bacterium.

Table 7. Percent recovery of Ralstonia solanacearum from surfaced-sterilized and nonsterilized $H y$ drocotyle bonariensis tissues following inoculation with two strains under greenhouse conditions ${ }^{\mathrm{z}}$

\begin{tabular}{lccccc}
\hline & \multicolumn{2}{c}{ Nonsterilized } & & \multicolumn{2}{c}{ Sterilized } \\
\cline { 2 - 3 } \cline { 5 - 6 } R. solanacearum strain & Root & Rhizome and petiole & & Root & Rhizome and petiole \\
\hline UTC & $0.0 \mathrm{~b}$ & $0.0 \mathrm{~b}$ & & $0.0 \mathrm{~b}$ & $0.0 \mathrm{~b}$ \\
RS 5 & $41.7 \mathrm{a}$ & $33.3 \mathrm{ab}$ & & $25.0 \mathrm{ab}$ & $25.0 \mathrm{ab}$ \\
UF 107 & $58.3 \mathrm{a}$ & $50.0 \mathrm{a}$ & & $41.7 \mathrm{a}$ & $33.3 \mathrm{a}$ \\
LSD $(P=0.05)$ & 36.1 & 34.4 & & 32.3 & 32.7 \\
\hline
\end{tabular}

${ }^{\mathrm{z}}$ Values were derived from 12 plants for each treatment. Sterilization of plant tissues was done by soaking in $70 \%$ alcohol for $5 \mathrm{~min}$ and then rinsing in sterile distilled water three times. Similar letters in each column indicates no significant difference according to least significant difference (LSD) test at $P \leq 0.05$. UTC $=$ untreated control.

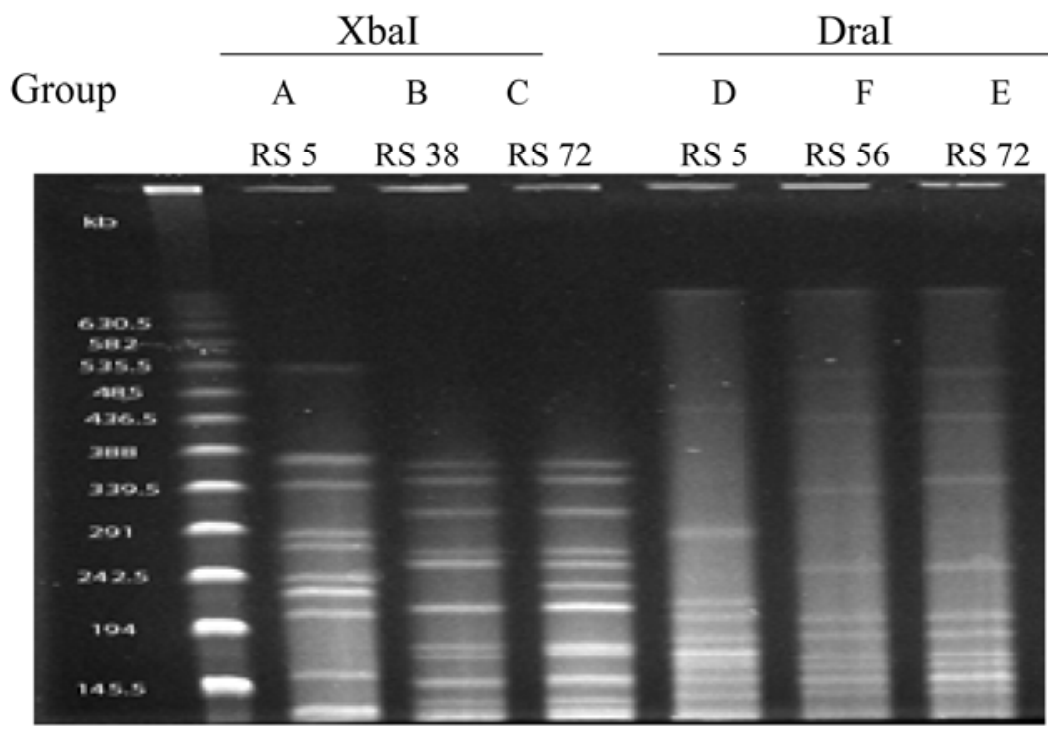

Fig. 2. Agarose gel showing the restriction endonuclease digestion profiles of total genomic DNA of Ralstonia solanacearum strains recovered from ponds in Gadsden County, FL in 2002. DNA was digested with $\mathrm{XbaI}$ or $\mathrm{DraI}$ and fragments were separated by pulsed-field gel electrophoreses. The first lane contains the 48.5- to 1,000-kb concatemer ladder (Boehringer-Mannheim Ingelheim, Germany).

Table 8. DraI and XbaI pulsed-field gel electrophoresis (PFGE) haplotypes of Ralstonia solanacearum strains from ponds 1 and 2 and infected plants in Gadsden County, FL in 2002

\begin{tabular}{llcc} 
& & \multicolumn{2}{c}{ PFGE group } \\
Serial no. & Origin of isolation/pond of origin & XbaI & DraI \\
\cline { 3 - 4 } RS 5 & Tomato & $\mathrm{A}$ & $\mathrm{D}$ \\
RS 37 & Geranium/pond 1 & $\mathrm{B}$ & $\mathrm{E}$ \\
RS 38 & Geranium/pond 1 & $\mathrm{B}$ & $\mathrm{E}$ \\
RS 48 & Tomato/pond 2 & $\mathrm{B}$ & $\mathrm{E}$ \\
RS 50 & Tomato/pond 2 & $\mathrm{B}$ & $\mathrm{E}$ \\
RS 52 & Water/pond 2 & $\mathrm{B}$ & $\mathrm{E}$ \\
RS 54 & Water/pond 2 & $\mathrm{B}$ & $\mathrm{E}$ \\
RS 55 & Bidens mitis pond 2 & $\mathrm{B}$ & $\mathrm{F}$ \\
RS 56 & Polygonum pennsylvanicum/pond 2 & $\mathrm{B}$ & $\mathrm{E}$ \\
RS 57 & P. pennsylvanicum/pond 2 & $\mathrm{B}$ \\
RS 58 & Hydrocotyle ranunculoides/pond 2 & $\mathrm{C}$ & $\mathrm{E}$ \\
RS 62 & Water/pond 1 & $\mathrm{B}$ & $\mathrm{E}$ \\
RS 64 & Water/pond 1 & $\mathrm{B}$ & $\mathrm{E}$ \\
RS 65 & Water/pond 2 & $\mathrm{B}$ & $\mathrm{E}$ \\
RS 66 & Bidens mitis/pond 2 & $\mathrm{B}$ & $\mathrm{E}$ \\
RS 67 & Water/pond1 & $\mathrm{B}$ & $\mathrm{E}$ \\
RS 70 & P. pennsylvanicum/pond 2 & $\mathrm{C}$ & $\mathrm{E}$ \\
RS 71 & Water/pond 2 & $\mathrm{B}$ & $\mathrm{E}$ \\
RS 72 & Water/pond 2 & $\mathrm{C}$ & \\
\hline
\end{tabular}


On the other hand, UF 107 was found on 75 and $66.7 \%$ of nonsterilized roots and rhizome or petiole respectively, and was found on $58 \%$ of the sterilized samples (Tables 6 and 7).

PFGE analysis of strains. Whole-cell DNA of $19 R$. solanacearum strains isolated from tomato and geranium plants, aquatic weeds, and ponds 1, 2, and 3 were digested with $X b a \mathrm{I}$ or $\mathrm{DraI}$ followed by PFGE, and six unique DNA fingerprints were observed (Fig. 2; Table 8). Digestion with $X b a I$ generated haplotypes designated as groups A, B, and C (Table 8) and DraI generated three haplotypes, designated groups D, E, and F. Groups A and D included strain RS 5 while group B included strains RS 37, RS 38, RS 48, RS 50, RS 52, RS 54, RS 55, RS 56, RS 57, RS 62, RS 64, RS 65, RS 67, and RS 71. Group C strains included strains RS 58, RS 70, and RS 72 (data not shown). Group E included strains RS 37, RS 38, RS 48, RS 50, RS 52, RS 54, RS 55, RS 57, RS 58, RS 62,
RS 64, RS 65, RS 67, RS 70, RS 71, and RS 72 while group F contained RS 56 (data not shown).

Phylogenetic analysis of strains collected from ponds and weeds. Based on phylogenetic analysis, all the strains isolated from pond 1 (RS 130, UF 105, and UF 107) and pond 2 (UF 108 and UF 312) along with strains isolated from infected geranium (RS 125, RS 128, and UF 334) and hydrangea (RS 118, RS 119, and RS 120) were $100 \%$ identical to RS 37 and

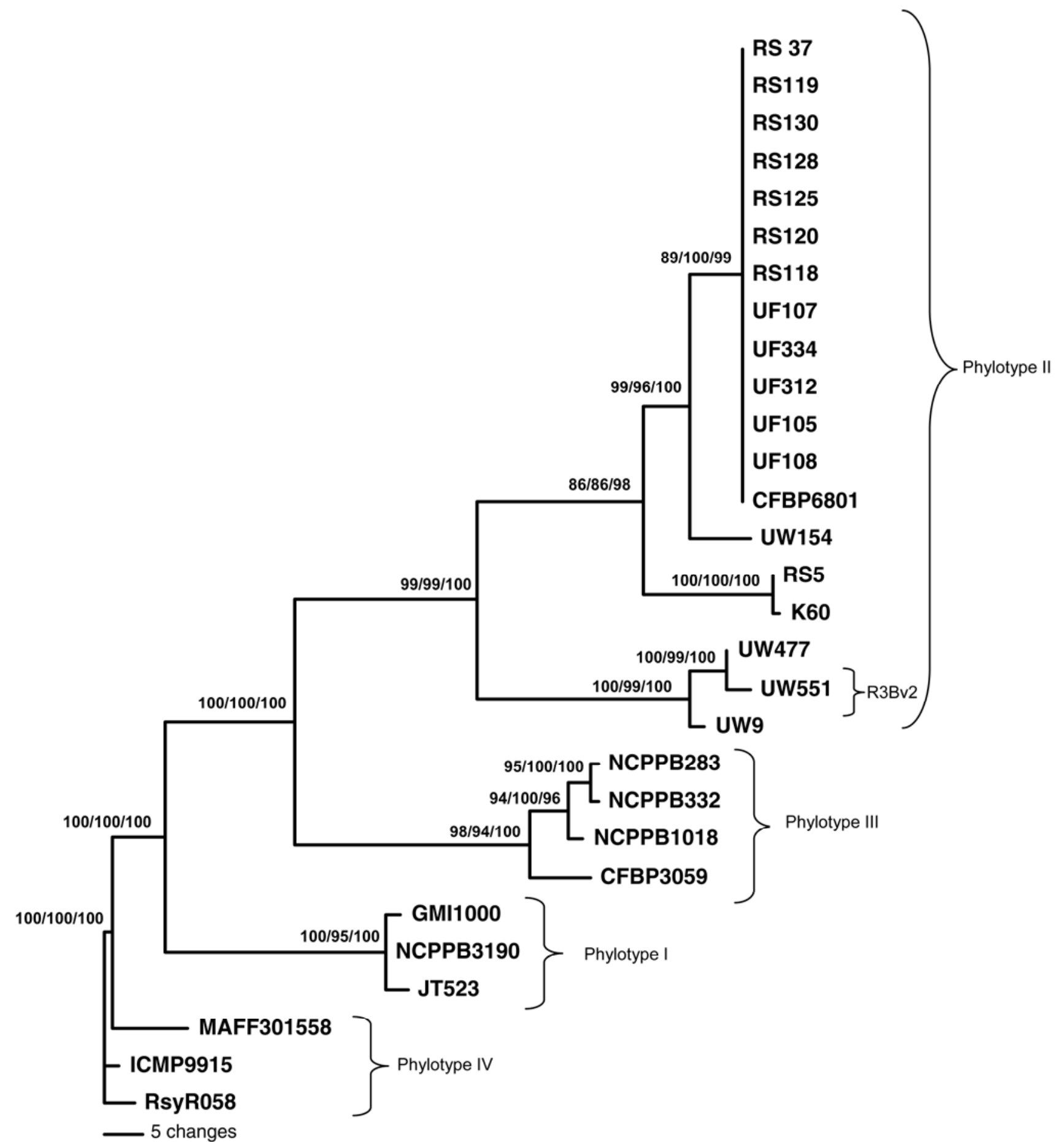

Fig. 3. Phylogenetic tree of Ralstonia solanacearum species complex, based on sequencing a 750-bp fragment of the endoglucanase (egl) gene from diverse $R$. solanacearum strains. In addition to sequences reported in this study, previously published sequences were selected to represent haplotypes (11,25). The first number is the bootstrap value for maximum parsimony analysis, the second number is the bootstrap for maximum likelihood analysis, and the last number is the posterior probability of trees created by Bayesian analysis. 
CFBP6801 (Fig. 3). RS 37, our reference strain, was isolated from a wilted geranium plant in 2001 and was the first strain isolated from the same facility where the other infected geranium and hydrangea plants were found. Based on sequence comparisons of the partial egl gene, UF 107 was determined to have $100 \%$ nucleotide identity with CFBP6801, sequevar 4NPB $(4,25)$, using Basic Local Alignment Search Tool (BLAST). Phylogenetic analysis also grouped UW154, sequevar 5, in the same clade with strains from this study. The indigenous Floridian strains, represented by RS 5, belong to sequevar 7 (Table 1).

\section{DISCUSSION}

Using genetic approaches and, in particular, phylogenetic analysis of $750 \mathrm{bp}$ of $e g l$, we determined that an exotic $R$. solanacearum strain designated phylotype II/4NPB has become established in two north Florida ponds. A previous study placed RS 37 in sequevar 5 (16); however, recent findings from Martinique place these exotic strains in phylotype II/4NPB based on phylogenetic analysis (26). Using PFGE analysis, we determined that the exotic strains were different from the native Florida strain. In water and plant samples collected in 2002, none of the strains showed the same banding patterns as the native strain. Preliminary host tests on pepper and tobacco showed that the exotic strain is able to cause wilt symptoms, unlike the native Floridian strains. Phylotype II/4NPB has a larger host range than other subclasses of $R$. solanacearum, including solanaceous, cucurbit, and ornamental plants (26). Reports from Martinique described R. solanacearum as being able to cause wilt in previously unknown hosts such as cantaloupe, watermelon, and pumpkin (27). Phylogenetic positioning places the Martinique sequevar four strains with those that are able to infect banana and plantain and cause Moko disease. However, when tested for pathogenicity on Musa spp., these new Martinique strains did not cause wilt symptoms, although they were able to move systemically in various parts of the plants (26). Pathogenicity on various hosts, including Musa spp. and members of the cucurbits family, will need to be tested with the strains collected from this study to confirm that they are truly phylotype II/4NPB.

As a result of sampling five different irrigation ponds on tomato farms and ornamental nurseries in Northern Florida associated with bacterial wilt from 2002 to 2005 , we determined that $R$. solanacearum was present in pond water and was associated with two semiaquatic weed species ( $H$. ranunculoides and $P$. pennsylvanicum) in the pond environment. We also determined that there was a correlation between average monthly air temperature and the ability to recover $R$. solanacearum from pond water. A statistically positive correlation between pathogen populations recovered on SMSA medium and ambient temperature was observed, and agreed with results for race 3 biovar 2 of $R$. solanacearum previously reported from the United Kingdom (7), the Netherlands (15), and Spain (3). In $2004 R$. solanacearum was first detected in April, when the temperature was above $17^{\circ} \mathrm{C}$. The bacterial populations were relatively high (from $3.5 \times 10^{2}$ to $5.6 \times 10^{4}$ ) from April to November, and then decreased dramatically until it was not detectable in December, when temperatures were below $17^{\circ} \mathrm{C}$. The majority of reports of incidence of the disease in northern Florida have been during the fall growing season, June to September, which is related to highest populations of the pathogen.

It is unknown how long the exotic strain has been established in the ponds tested in this study. For pond 1, it was possibly introduced on infected geranium in 2001, or a series of introductions may have occurred; however, it is difficult to speculate on the origin of this strain in pond 2 given that this pond is 5 miles away from pond 1 . One possibility is that movement may have occurred through the underground river system common to northern Florida.

Previous studies have shown the importance of irrigation water and alternative weed hosts for maintaining populations of $R$. solanacearum for extended periods of time (15). Based on this, we selected ponds that were located near fields that had reported problems with bacterial wilt. In our study, pathogen populations varied between ponds. The bacterium was shown to persist in ponds 1 and 2 but was found inconsistently or was undetected in ponds 3,4 , and 5 . One major difference for each pond was the population of aquatic weeds. In ponds 1 and 2, both $H$. ranunculoides and $P$. pennsylvanicum grew abundantly whereas, in the other ponds, neither weed was present, possibly due to the nearby trees blocking the sunlight to levels that may adversely affect growth. We also believe that the aquatic weeds were unable to establish themselves in pond 4 because it was dry until April 2004.

We found that $H$. ranunculoides and $P$. pennsylvanicum harbor significant populations of $R$. solanacearum. The bacterium was consistently detected on the stems and roots of these aquatic weeds May through November. Inoculation of two different Hydrocotyle spp. under greenhouse conditions indicated that, after wilting, plants produced new growth that was latently infected and from which the bacterium could be detected. Based on the Hydrocotyle inoculation tests in which the Caribbean strain caused more wilt symptoms and was detected on a higher percentage of these plants than the native Floridian strain, it is plausible that the exotic strain is able to adapt successfully to the environ- mental conditions of north Florida and compete with the native strain. Hydrocotyle spp. potentially could serve as a perennial host and source of inoculum throughout the year. Therefore, the elimination of aquatic weeds that may be potential alternative hosts could be part of an integrated management strategy for the control of bacterial wilt.

\section{LITERATURE CITED}

1. Ausubel, F., Brent, R., Kingston, R., Moore, D., Seidman, J., Smith, J., and Struhl, K. 1998 Current Protocols in Molecular Biology. John Wiley and Sons, New York.

2. Buddenhagen, I., and A. Kelman. 1962. Designation of races in Pseudomonas solanacearum (Abstr.) Phytopathology 52:726

3. Caruso, P., Palomo, J. L., Bertolini, E., Álvarez, B., Lòpez, M., and Biosca, E. 2005. Seasonal variation of Ralstonia solanacearum biovar 2 populations in a Spanish river: recovery of stressed cells at low temperatures. Appl. Environ. Microbiol. 71:140-148.

4. Collection Française de Bactéries Phytopathogènes. 2006. Catalogue de souches bactériennes, 7th ed. Institut national de la $\mathrm{Re}$ cherche Agronomique.

5. Denny, T. 2006. Plant pathogenic Ralstonia species. Pages 573-644 in: Plant Associated Bacteria. Samuel S. Gnanamanickam, ed. Springer, Dordrecht, The Netherlands.

6. Egel, D. S., Graham, J. H., and Stall, R. E. 1991. Genomic relatedness of Xanthomonas campestris strains causing diseases of citrus. Appl. Environ. Microbiol. 57:2724-2730.

7. Elphinstone, J. G., Stanford, H. M., and Stead, D. E. 1998. Survival and transmission of Ralstonia solanacearum in aquatic plants of Solanum dulcamara and associated surface water in England. Bull. OEPP 28:93-94.

8. Englebrecht, M. C. 1994. Modification of a semi-selective medium for the isolation and quantification of Pseudomonas solanacearum. Bacterial Wilt Newsl. 10:2-5.

9. EPPO/CABI. 2000. Data sheets on quarantine pests Ralstonia solanacearum. EPPO quarantine pest. CAB International, Wallingford, UK.

10. EPPO/CABI. 2004. Optimized protocols for diagnosis of potato brown rot and bacterial wilt and detection of the causal bacterium (Ralstonia solanacearum) in infected plants, surface water, soil, industrial potato waste and sewage. CAB International, Wallingford, UK.

11. Fegan, M., and Prior, P. 2005. How complex is the Ralstonia solanacearum species complex? Pages 449-461 in: Bacterial Wilt: The Disease and the Ralstonia solanacearum Species Complex. C. Allen, P. Prior, and A. C. Hayward, eds. American Phytopathological Society, St. Paul, MN.

12. Hayward A. C. 1991. Biology and epidemiology of bacterial wilt caused by Pseudomonas solanacearum. Annu. Rev. Phytopathol. 29:6587.

13. Huelsenbeck, J. P., Ronquist, F., Nielsen, R., and Bollback, J. P. 2001. Bayesian inference of phylogeny and its impact on evolutionary biology. Science 294:2310-2314.

14. Hong, J. C., Ji, P., Momol, M. T., Jones, J. B., Olson, S. M., Pradhanang, P., and Guven, K. 2004. Ralstonia solanacearum detection in tomato irrigation ponds and weeds. First Int Symp. Tomato Dis. 19th Annu. Tomato Dis. Workshop.

15. Janse, J. D., Araluppan, F. A. X., Schans, J., Wenneker, M., and Westerhuis, W. 1997. Experiences with bacterial brown rot Ralstonia solanacearum biovar 2, race 3 in the Netherlands. Pages 146-152 in: Bacterial Wilt Dis- 
ease. Molecular and Ecological Aspects. P. Prior, Allen, and J. G., Elphinstone, eds. Springer-Verlag, Heidelberg, Germany.

16. Ji, P., Allen, C., Sanchez-Perez, A., Yao, J., Elphinstone, J. G., Jones, J. B,. and Momol, M. T., 2007. New diversity of Ralstonia solanacearum strains associated with vegetable and ornamental crops in Florida. Plant Dis. 91:195-203.

17. Kelman, A. 1953. The bacterial wilt caused by Pseudomonas solanacearum. A literature review and bibliography. N. C. Agric. Exp. Stn. Tech. Bull. 99. North Carolina State University, Raleigh.

18. MIDI. 1992 MIDI, Microbial Identification System Operating Manual Version 4. MIDI, Inc., Newark, DE. Retrieved June 17, 2005 , from http://www.midiinc.com/media/pdfs/Tech Note101.pdf.

19. Olsson, K. 1976. Experience of brown rot caused by Pseudomonas solanacearum in Sweeden. Bull. OPPE 6:199-207.

20. Persson, P. 1998. Successful eradication of
Ralstonia solanacearum from Sweden. Bull. OEPP/EPPO 28:113-119.

21. Posada, D., and Crandall, K. A. 1998. Modeltest: testing the model of DNA substitution. Bioinformatics 14:817-818.

22. Pradhanang, P. M., and Momol, M. T. 2001. Survival of Ralstonia solanacearum in soil under irrigated rice culture and aquatic weeds. J. Phytopathol. 149:707-711.

23. Pradhanang, P. M., Momol, M. T., Dankers, H, Momol, E. A., and Jones, J. B. 2002. First report of southern wilt caused by Ralstonia solanacearum on geranium in Florida. Online. Plant Health Progress doi:10.1094/PHP-20020611-01-HN. http://www.plantmanagementnet work.org/pub/php/brief/geranium/

24. Swofford, D. L. 2003. PAUP*: Phylogenetic Analysis Using Parsimony (* and Other Methods), version 4.0. Sinaure Associates, MA

25. Van Elsas, J. D., Kastelein, P., De Vries, P. M. and Van Overbeek, L. S. 2001. Effects of ecological factors on the survival and physiology of Ralstonia solanacearum bv. 2 in irrigation water. Can. J. Microbiol. 47:842-854.

26. Wicker, E., Grassart, L., Coranson-Beaudu, R. Mian, D., Guilbaud, C., Fegan, M., and Prior, P. 2007. Ralstonia solanacearum strains from Martinique (French West Indies) exhibiting a new pathogenic potential. Appl. Environ. Microbiol. 73:6790-6801.

27. Wicker, E., Grassart, L., Mian, D., CoransonBeaudu, R., Dufeal, D., Guilbaud, C., and Prior, P. 2002. Cucmis melo, Cucumis sativus, Cucurbita moschata, and Athurium spp., new hosts of Ralstonia solanacearum in Martinique (French West Indies). Bacterial Wilt Newsl. 17:20-21.

28. Yabuuchi, E., Kosak, Y., Yano, I., Hotta, H. and Nishiuchi, Y. 1995. Transfer of two Burkholderia and an Alcaligenes species to Ralstonia gen. nov. Proposal of Ralstonia picketti (Ralston, Palleroni and Doudoroff 1973) comb. nov., Ralstonia solanacearum Smith 1896) comb. nov. and Ralstonia eutropha (Davis 1969) comb. nov. Microbiol. Immunol. 39:897-904. 